\title{
Masculinity and National Identity on the Early American Stage
}

\author{
Sarah E. Chinn*
}

Hunter College

\section{Abstract}

This essay explores how the early American stage functioned as an incubator for ideas about national identity, artistic expression, and masculinity. Reading four plays from the early years of the Republic - Royall Tyler's The Contrast, William Dunlap's André, John Augustus Stone's Metamora, and Robert Montgomery Bird's The Gladiator, I demonstrate how early American drama addressed changing concepts of ideal masculinity, republican democracy, and the colonial past.

In 1832, William Dunlap laid out what he considered to be the credo of the early American theater:

Inasmuch as we may hereafter deviate from the models left to us by our ancestors, it will only be, as we hope, in a more severe and manly character, induced by our republican institutions, and approaching the high tone of the Greek drama.... A people literally self-governed, and guided by the experience and accumulated science of Asia, and Africa, and Europe, must appreciate liberty and feel patriotism as no other people did. (89-90)

In this paragraph, Dunlap lays out some basic ground rules for the dramatic art of the early Republic: that it take into account but ultimately leave behind the European past; that it be embodied through a combination of manliness and patriotism; that it perform the experience of liberty that is intrinsic to a republican sense of self; that in its modernity and uniqueness it also replicate the seriousness and literary quality of the ancient world.

This essay will explore how the early American stage functioned as an incubator for ideas about national identity, artistic expression, and masculinity. The years of the early republic were, as many scholars have argued, a time in which Americans of all classes were deeply involved in the work of constructing a national identity through a variety of venues: oratory, print culture, scientific inquiry, to name a few. And, as Dana Nelson has shown, perceived bonds between men, particularly White men, motivated a great deal of cultural production in the nation's early years. Given the possible competition between men of various classes, national origins, and political positions, "white manhood' was a useful category for inventing national unity because it abstracted men's interests out of local issues and identities in an appeal to a nationally shared "nature" " (Nelson 7).

As Nelson observes, the mandate for what she calls "national manhood" was communicated through a variety of genres: essays, scientific tracts, novels, even the text of the US Constitution itself. But I would argue that one of the primary mechanisms for the communication of cultural values during the years of the early republic (roughly 17901830) was the theater, a vibrant laboratory of highly wrought emotion, patriotic claims, and a variety of national and regional "types" that a surprisingly high proportion of Americans sought out and had access to. Jeffrey Richards has shown that by 1790 , "nearly every coastal city of size, as well as many smaller towns and such inland locales as 
Richmond, had some professional or semi-professional theatrical troupe performing in public venues" (Richards 1), and playgoing was an activity for Americans rural and urban, wealthy and poor, merchant and artisan, Black and White. No wonder, then, that American-authored plays of the period engaged so actively with questions of national identity, which was inextricable from appropriate masculinity.

The stage had long been a subject of contention in the North American colonies, particularly in New England, in which professional theatrical performances were strongly discouraged and even banned until the late 18th century. ${ }^{1}$ As Dunlap observed, not so distant historically from the years of this struggle,

the south, from the universally admitted character of its population, was best fitted for the reception of the drama. The Presbyterians of the New-England provinces were opposed to any innovations upon their ascetic habits .... The Quakers of Philadelphia were of all people the most opposed to scenic representations. (16)

So it's not surprising that the first theater in the colonies was established in Williamsburg, VA, in 1716, followed by New York in 1732 and Charleston, SC in 1736. While companies from Britain and the West Indies visited the colonies on extended tours, the first company to settle in America was Lewis Hallam's London (later American) Company, who initially set up shop in Williamsburg, VA in 1752, and from there traveled up to New York to establish a playhouse on Nassau Street. Philadelphia, too, became a thriving center for theatrical production from the early 1790s, interrupted only by the yellow fever epidemic of 1793 (which itself forced the fledgling Philadelphia Company to decamp to Baltimore and found a theater there as well). ${ }^{2}$ By the end of the 18th century, every major city and town had at least amateur theatricals, and most had professional companies (although of varying quality).

Early American drama trafficked primarily in Shakespeare, melodrama (which, as Bruce McConachie has shown, can embrace a number of subgenres, including heroic melodrama, historical tragedy, what he calls "apocalyptic melodrama," moral reform melodrama, and the like) and farce, and evenings at the theater were long, comprising a "serious" play, an "afterpiece" (most commonly a comedy) and occasionally entr'actes of songs or other kinds of performance. ${ }^{3}$ As Jeffrey Richards has argued, British plays and English-language translations of French and German plays, dominated the American stage. However, while American audiences demanded the plays that echoed familiar themes and playwrights often simply adapted their work from pre-existing European dramas, not all texts could be so easily transported over the Atlantic. In a culture that heroized democracy, playwrights struggled with the challenge of creating a democratic hero. The new American hero certainly could not be an aristocrat, but had to be imbued with a kind of Jeffersonian "natural aristocracy" that raised him above his peers as a kind of first among equals. As David Grimsted points out, "the democratic hero, rather than rising above society either by his nature or in defiance, measured himself superlatively to its standards" (207).

The stage was in many ways a perfect arena in which to work through difficult questions of national and masculine identity. The primary genre of the early American stage, melodrama, required the expression of extreme emotion and the declamation of deeply held beliefs that had few other outlets. While oratory was, of course, a significant mode of public communication of ideas, early republican oratory depended upon the concept of "natural language" and the transparency of expression. Jay Fliegelman has shown that by the mid-18th century, "the virtuosity of manipulating arguments gives way to the aural and moral spectacle of sincerity; the credibility of the speaker and not the credibility of the argument becomes paramount" (43). Even though oratory depended on a high 
level of theatrical skill to convince audiences of its own authenticity, theatricality was an accusation rather than an asset. ${ }^{4}$ Fliegelman quotes a letter from John Adams to Benjamin Rush that characterized the Declaration of Independence as "a theatrical show" in which "Jefferson ran away with all the stage effect ... all the glory of it" (qtd. 93). Certainly, part of Adams's response was sour grapes, but he also suggests that the theatricality of the rhetoric of the Declaration allowed Jefferson to reap unfair praise from his perhaps naïve auditors, rather than depending upon the transparent truths of his message.

By contrast, melodrama depends upon hyperexpressiveness that necessarily exceeds authenticity; it is, in Peter Brooks's words, "the aesthetics of astonishment," which "exteriorizes conflict and psychic structure" (35). Melodrama turns characters inside out, exposing their most hidden and chaotic feelings even as it communicates them in outsize language and gesture; it "starts from and expresses the anxiety brought by a frightening new world in which the traditional patterns of moral order no longer provide the necessary social glue" (Brooks 20). In a new country in which men were reworking their most basic political relationships, theater could offer at least some of that glue through representing examples of manhood, American and not - it could provide some clues as to how American men could construct "national unity and sameness ... recodified as the territory of national manhood" (Nelson 12-13). In the melodramas, and in part the comedies, of early American theater, men in the audience could watch men up on stage attempt, succeed, and fail at forging that unity. They could identify and diagnose the shortcomings of men different from themselves, separated either by historical distance or national and ethnic difference, and recognize and emulate men whose values best embodied American democratic heroism.

More often than not, in the early years of the republic, this function was performed by historical tragedies, which borrowed many of the generic conventions of melodrama (musical interludes and background music more generally, emotional hyperexpressiveness, and, as I'll show below, an investment in limning masculine identity). While these plays borrowed somewhat from Shakespearean drama in their use of iambic pentameter and their tragic endings, I would argue that historical tragedies are closer to the genre of melodrama more generally. Like other melodramas, they represented not just historical events but the threat of social disorder to both the body politic and to the domestic sphere. Spartacus and Metamora are world-historical figures, but they're also husbands and fathers, tasked with maintaining their families as well as their armies.

In the space that remains, I'd like to analyze several early American plays in which male characters embody various models of how to perform masculinity and how theater provided mechanisms by which different kinds of manhood could be explored and understood. The first, The Contrast (1787), is by now a classic of the early US stage - the first play by an American playwright, performed on an American stage, with an explicitly American theme. Based in tone on the oevre of Richard Brinsley Sheridan and the Restoration comedy style that Sheridan's work revived, The Contrast oscillates between heroizing and deflating its virtuous leading male, Colonel Manly, a decommissioned officer in the Continental army.

Several plays of the period dealt with the Revolutionary War, but none more controversially than William Dunlap's André. The play struggles with a variety of masculine models - the stoic martyr, the headstrong boy, the cynical functionary, and, of course, the heroic General, Washington himself. Presented almost 20 years after the war's end, the play takes stock of the kinds of masculinity available to White men in the early years of the republic, ultimately holding Washington up as a desirable, though possibly inaccessible, model. 
The last two plays I'll be discussing were both commissioned for the leading actor of the 1820 s to 1840 s, Edwin Forrest. It is no coincidence that two of them Metamora, whose protagonist is a fictionalized version of Metacomet or King Philip who fought the British in King Philip's War of 1675-1676, and The Gladiator, a retelling of the story of Spartacus, leader of the slaves' rebellion against Rome in the first century BCE - lived and died centuries before and, in Spartacus's case, thousands of miles away from the historical time and place in which the plays were written. The hyperexpressiveness of the stage creates one kind of distance, as does the physical raising of the stage above the bodies of the audience. However, I'd argue that in setting their action so far away historically and/or geographically, these plays use spatial and temporal distance like protective gloves, to work with material that would otherwise be too hot to handle. As the nation grew chronologically further from the revolutionary generation, many plays of the 1820 s and 1830 s looked to the more distant past for guidance.

\section{"Exult, Each Patriot Heart!': Comedic Masculinity and American Virtue}

Starting with its Prologue The Contrast is unambiguous about the claim it lays to its American audience. "Exult, each patriot heart," it crows, "this night is shewn/A piece, which we may fairly call our own." The Prologue goes on to praise the republican disregard for titles of rank or aristocracy, and asks "Why should our thoughts to distant countries roam,/When each refinement may be found at home?" (7). This asseveration is picked up later in the play in a conversation between Manly and his Europhilic counterpart Billy Dimple (né Van Dumpling):

DIMPLE: Colonel, I presume you have been in Europe?

MANLY: Indeed, Sir, I was never ten leagues from the continent.

DIMPLE: Believe me, Colonel, you have an immense pleasure to come; and when you shall have seen the brilliant exhibitions of Europe, you will learn to despise the amusements of this country as much as I do.

MANLY: Therefore I do not wish to see them; for I can never esteem that knowledge valuable which tends to give me a distaste for my native country.

The play explicitly works through any number of contrasts, and that between the virtuous Manly and the rakish, debt-ridden, deceitful, Anglophilic Dimple is among the most marked. Manly places the well-being of the soldiers formerly under his command above his own pleasures in the city; he honors his parents and longs to return to their home in the country; he refuses to cash in his military pay until he knows the fledgling government can support the cost; he defends his sister Charlotte's honor against the libertine Dimple; and he ends up with the virtuous and sentimental Maria, rescuing her from a potentially disastrous marriage to Dimple. Dimple, by contrast, is a rake and a libertine (he plans to marry Maria for her money and still woo Charlotte and her friend Letitia), a gambler, a debtor, and a fop.

The play seems, then, to present us with a clear-cut contrast between the virtuous rural soldier Manly and the ill-intentioned city boy/Europe-loving Dimple. Where Dimple excoriates American values and American cultural expression, Manly praises it. But the actor who plays Manly is not the one who recites the Prologue is not the one who launches the opening salvo for patriotic pride. Rather, the Prologue was written to be declaimed by Thomas Wignell, a star comic actor, who played Manly's country bumpkin "waiter," Jonathan. 
What does it mean that Wignell/Jonathan lays out the template through which The Contrast should be read? While Jonathan, like Manly, is burgeoning with patriotic pride, he has none of Manly's natural aristocracy. Indeed, Jonathan is forced to affirm his status as a new American man in his first interactions with Jessamy, Dimple's valet. When Jessamy identifies Jonathan as "Colonel Manly's servant," Jonathan is outraged by this challenge to his solidarity with Manly that is achieved through the concretizing of White masculinity:

Servant! Sir, do you take me for a neger? I am Colonel Manly's waiter .... I am a true blue son of liberty, for all that. Father said I should come as Colonel Manly's waiter, to see the world, and all that; but no man shall master me. My father has as good a farm as the colonel. (25)

Jonathan's identity as a new American man is inextricable from Whiteness and defined through ownership of property, qualities that were about to be inscribed within the US Constitution and the inaugural legislation of the US Congress, which limited naturalization of US citizens to Whites (and explicitly excluded "vagrants," "paupers," and "bad men"; that is, men who were not rooted to their place in the new nation by a combination of property and virtue [Takaki 14]). As the US approached the codification of its status as a nation, it was clear that only White men could claim an identity as "a true blue son of liberty," and possession of one's self and of land defined both masculine exceptionalism (the United States is unique among nations) and normalization (this is what it means to be an American).

Despite Jonathan's attempts to draw Manly into a rhetorical fraternity via the shared values of liberty, property, and White supremacy, where Manly's lack of experience of the world outside the United States is represented as a virtue, Jonathan's naïveté about the sophisticated urban world he has just entered is played for laughs. Wanting to visit Trinity Church, he is sent to a neighborhood notorious for prostitution; swearing he would never visit a theater he ends up watching a play despite himself; and attempting to woo Jenny, a young servant girl introduced to him by Jessamy, he is summarily rejected because of his witless misreading of Jessamy's (admittedly ridiculous) coaching. At the same time, Jonathan is represented as a genuine American type, the Yankee, that while closely related to the comic Irishmen and country folk of Britain (roles that brought Wignell his fame) is not the same due in large part to the Yankee's claim to absolute social equality with other "sons of liberty.",

Tyler simultaneously champions American masculine specificity and bifurcates that specificity between a hero and a buffoon. In a recent article, Mark Caldwell argues that in The Contrast Tyler negotiates the cultural competition between country and city, "in which New York was at once celebrated and offered an opportunity for improvement in its dialogue with the unpolished yet sound manners of the country and the highly developed but suspect codes of urban Europe" (321). With an ever-increasing market economy, the new nation depended heavily on its urban centers, even as ideologically it heroized its rural folk ${ }^{6}$; moreover, as Michael Warner has shown, with the circulation of broadsheets, newspapers, and other artifacts of print culture, the line between urban and rural thinned considerably.

In The Contrast, then, manliness requires a delicate balance, avoiding the sleek knowingness of Europe while at the same time improving upon the rough naïvete of rural life. The ideal new American man is confident but not arrogant, devoted to the countryside but not provincial or parochial, urbane but not snobbish, patriotic but cosmopolitan, performative but not theatrical. And ironically, the theater was one of the best places to find exempla of this figure, however, difficult they might be to emulate. 


\section{"The Destiny of Millions": National Identity and the Limits of Virtue}

While The Contrast locates the threat to American masculinity in both unreflective Europhilia and rural provincialism, it does not address a larger and certainly more urgent problem of the period: how to understand and integrate formerly Loyalist men into the polity. If part of the work of the new nation was to forge fraternal bonds between White men through the rhetoric of virtuous manhood and the joys of republican democracy, then those men of all classes who sided with the British, who chose monarchy over democracy, posed a serious conceptual (not to mention political) problem.

William Dunlap's André takes this conundrum on directly. Dunlap himself came from a Loyalist family (although he himself supported the revolution and joined the near-cult of Washington), and as a central figure in the theatrical world of the late 18th century, it could not have escaped his notice that the British authorities looked far more fondly on the theater than their American antagonists (at the outbreak of hostilities in 1774, the Continental Congress banned all theatrical productions, and plays returned to New York only after the British occupation in 1776). Indeed, John André himself was involved in the life of the stage when he was part of the British army in Philadelphia. André's execution for espionage was a cause for significant controversy, and cast a shadow over Washington's judgment - no less a figure than Alexander Hamilton, then Washington's aide-de-camp, lamented André's death: "My feelings were never put to so severe a trial... Never perhaps did a man suffer death with more justice, or deserve it less" (qtd. in Rinehart 273). The unusual sympathy felt for André put the moral authority of Washington in particular and the ideology of a confraternity of virtuous men in general in question, and Dunlap's André does its best to grapple with the ramifications of this conflict.

The plot of André is simple: John André has been arrested for espionage and is scheduled to be hanged. A young American soldier, Arthur Bland, who had been saved from death by André during a stint as a prisoner-of-war, learns of André's fate and swears to save him, if not from execution then at least from the indignity of being hanged as a spy rather than shot as an enemy soldier. In the meantime, Bland's father is being held by the British, who are threatening to kill him if André's execution goes through. "The General," Washington, must decide whether and how André is executed, and he refuses to be swayed from his command that André be hanged.

From the beginning, Dunlap represents the British forces as equal adversaries for the Continental army: as Bland characterizes his experience on the battlefield, "The Briton, there, plays at no mimic war;/With gallant face he moves, and gallantly is met" (515). But the analogy is not wholly accurate, given André's status as a spy. Even as the General sings the praises of patriotic devotion - "O patriotism!/Thou wond'rous principle of god-like action!/Wherever liberty is found, there reigns/The love of country" (519) André recalls how his personal ambition clouded his own love for his native land and his duty to the rules of engagement.

André represents its eponymous hero as an ideal man: virtuous, self-sacrificing, noble, eloquent, courageous, generous. The General is equally virtuous, but unlike André he is responsible not only for his own character, but for the fate of the nation. For his part, Bland values the virtue of both men, but is incapable of emulating their gravitas. He is a "[r]ash, headstrong, maddening boy!" (536), whose personalizing of the case against André clouds his judgment. He denies that André was even a spy, and accuses M'Donald of cowardice. Indeed, M'Donald maintains that Bland's passionate defense of André is ultimately a kind of narcissism and pride, much like André's own pride and ambition, which, in André's telling of the events that led to his arrest, left him vulnerable to Arnold's plot: 
Pleas'd with the honours daily shower'd upon me,/I glow'd with martial heat, my name to raise/Above the vulgar herd, who live to die,/And die to be forgotten..../Nothing then I saw/But confidential favour in the service,/My country's glory, and my mounting fame. (525)

André's mistake was to see the praise he received for his military success as a reflection upon his status, his ability to rise "above the vulgar herd," rather than a confirmation of his duty to his country and his honor. As the General reminds us, the purest and most virtuous actions have (or should have) no connection to personal motives of any kind, however, well intentioned those motives are.

Virtuous manhood in this play is a product of maturity, that is of being a man rather than a boy, and of masculine self-restraint. These two qualities do not necessarily go hand in hand, and, indeed, André's surrender to ambition is in many ways worse than Bland's boyish impetuousness. After, all, Bland might, with adequate guidance and training, outgrow his rashness to become a modulated, temperate man. André, on the other hand, is not satisfied by the intrinsic prize of virtuous service to the nation, but looks beyond to material and, more importantly and dangerously, historical rewards - André wants, in effect, to game history and gain immortality now.

By contrast, the General sees posterity not as his reward but as his responsibility. The General's refusal to change André's sentence is the result not of revenge (M'Donald's motivation, after the death of his child) or cynical maneuvering (as the General's other aide Seward claims), but a commitment to the nation's future. Not only will commuting the sentence encourage British abuse of American troops, particularly prisoners-of-war, but it will harm future Americans. In order to safeguard the success of the revolution and the national security of those yet to come, the General must hold fast: "the destiny of millions, millions/Yet unborn, depends upon the rigour/Of this moment" (535). While M'Donald looks to past experience for his justification for André's punishment, and Bland invokes his own past as reason to save his friend, and Seward talks about current exigencies, the General imagines a postrevolutionary America that must evoke the respect of other nations.

This ideal of disinterested masculinity - contrasted with the boyish passion and female investment in family ties that characterize Bland and his mother - might be admirable, but it is exceedingly difficult to emulate, particularly in a world that was becoming increasingly shaped by the exigencies of the market. As Michael Zakim argues, "capitalism's emerging domination of American life [was] the central event of antebellum history" (5). ${ }^{7}$ While I'm not sure I would accept quite such a sweeping diagnosis, it is true that Dunlap's implicit claim that postrevolutionary audiences would do well to learn from André's single lapse into self-aggrandizement and the General's contrasting detachment from self-interest would become increasingly at odds with the ethos of the new republic, and that the unifying force of a common good would be continually threatened by the profit motive.

If national stability depended upon disinterested loyalty to the abstraction of the nation, then the new republic was on shaky ground indeed. Moreover, if taking the long view was a prerequisite to virtuous masculinity, then it would be more difficult to define immediate investment in growing capital and one's share in the market as being in the national interest in the long run. It is not surprising, then, that as market forces increasingly defined White men's place within the political and economic spheres (and as women were ever more pushed to the sidelines, Native Americans "removed" further west, and free Blacks legislated out of the body politic) that dramatic explorations of male identity looked to the past for explanations of virtuous masculinity. 


\section{"I Thank the Gods There Are Barbarians": Raiding the Savage Past}

This conflict between disinterested virtue and motivated action did not wholly dissolve in the early years of the 19th century, but it certainly became less pronounced. For example, in her 1815 play The Fair Americans, Mary Carr Clarke lampoons recruiting agents trying to round up volunteers for the ongoing War of 1812, and while the young hero invokes the patriots of 1776 in his desire to sign up, various "countrymen" refuse to fight, claiming kinship with neighboring Canadians, and a lack of motivation for the war. As one argues, "in the revolution of "76 I followed the brave Montgomery to the Plains of Abraham, but now I won't fight till I know what for" (194).

On the stage, American-authored dramas dealing with contemporary issues decreased in number, and playwrights increasingly mined the past at home and abroad to interrogate contemporary American masculine identity. The War of 1812 had caused major political rifts that threatened the unity of the White male citizenry, and the expansion of the franchise beyond property owners to all White men over 21 exacerbated pre-existing fractures along the lines of class, rural/urban splits, and region. The growing focus on individual achievement and acquisition "required individual men to internalize in terms of personal responsibility the political and economic vicissitudes of the early nation" (Nelson 62). By casting their gaze back to a communal, pre-capitalist past in which the divisions between masters and slaves, colonizers and colonized were politically, economically, and morally unambiguous, playwrights of the 1820s and early 1830s wove together models of manhood that, while ultimately insufficient for their spectators, went some way towards reassuring their male audiences that heroism had a time and place, even if that time was not now and that place was not now.

The two plays that best encapsulate these anxieties are John Augustus Stone's Metamora; Or, the Last of the Wampanoags (1829) and Robert Montgomery Bird's The Gladiator (1831). Both plays were written for one of the leading tragedians of the American stage, Edwin Forrest, who organized an annual playwrighting contest: the winner won $\$ 500$ and his play would be performed with Forrest in the lead role. Forrest was famed for his muscular appearance and equally muscular performances, and Spartacus in The Gladiator and Metamora were typical roles for him: noble leaders who were doomed to destruction by a combination of their own tragic flaws and historical inevitability.

American Indians were a popular topic of fiction and drama in the 1820s, and few historical Indians were more often represented than Metacom, on whom Metamora is based. In Stone's play, Metamora represents the tensions between communal duty and individual honor, between democracy and leadership. According to the play, Metamora's virtues are legion: he killed a panther to protect a young White woman; he never forgets a kindness done to him; he is fearless; he is hospitable. Like other stage Indians, he is in communion with nature and inhabits a natural aristocracy, and tied to the land, as he avers, "Never will Metamora forsake the home of his fathers, and let the plough of the strangers disturb the bones of his kindred" (21). The young hero of the play, Walter, recognizes that Metamora cannot be domesticated, since " 'twould cost him half his native virtues. Is justice goodly? Metamora's just. Is bravery virtue? Metamora's brave ... [H]is worship, though untaught and rude flows from his heart, and Heaven alone must judge of it" (12).

Needless to say, relations between the Wampanoag and the English deteriorate over the course of the play. Unable to control his rage at a traitorous fellow Wampanoag, Metamora murders him and calls for vengeance on the White colonizers: "the wrath of the wronged Indian shall fall upon you like a cataract that dashes the uprooted oak down 
the mighty chasms" (23). He then leads the Wampanoag into battle, invoking "the bright lakes which the Great Spirit gave you when the sun first blazed with the fires of his touch .... Call on the happy spirits of the warriors dead, and cry 'Our lands! Our nation's freedom! Or the grave!'” (36). Echoing Patrick Henry's "give me liberty or give me death" speech, Metamora calls upon the communal power of the Wampanoag, dead and alive, to defeat the British settlers.

By the end of play, however, Metamora is alone with his wife, Nahmeokee, and their son, killed by British guns. Separated from his nation, Metamora is at once heroic and doomed, having provoked a battle to the death that he cannot win. Strikingly, though, the play ends not with British victory, but with Metamora's final curse against his White enemies: "May your graves and the graves of your children be in the path the red man shall trace! And may the wolf and panther howl o'er your fleshless bones" (40).

Metamora's heroism is tempered by his rage and easy shift from verbal conflict to physical violence. Extra-legal violence was epidemic in the early Republic, not only in interpersonal conflicts (see, for example, Ruth Bloch's work on wife beating, Richard Bell's discussion of dueling, and Scott C. Martin's analysis of anxieties about intemperance and violence in the late 18th and early 19th centuries), but in large-scale actions such as riots. As David Grimsted has shown, mob violence and rioting were a significant element of antebellum US life (Grimsted tracks over twelve hundred riots between 1828 and 1865), what he calls "a stomach-churning catalog of butchery" (91). Rioting was, as Grimsted demonstrates, primarily an activity engaged in by White men, and represented the failure of codes of masculine self-restraint and military virtue, a failure that presages Metamora's fall. Metamora abandons himself to rage and revenge, and ultimately sacrifices both domestic contentment, facing the death of his son and his sacrifice of his wife, and the integrity of the Wampanoag people itself. The cautionary tale for White male playgoers is clear here: control your rage and unruliness or risk the loss of family and nation.

Like Metamora, The Gladiator engages questions of male self-restraint and rage, and negotiates the tension between a mass movement and the responsibilities of leadership, and ends up ambivalently siding with the latter. Kidnapped from Thrace and impressed into gladiatorial combat, Spartacus resists the corruption of the arena, arguing "I will contend with mine enemy when there is strife between us ... but I will not slay a man for the diversion of the Romans" (317). He links Rome's wealth with its corruption, claiming that "if Romans had not been fiends, Rome had never been great! Whence came this greatness, but from the miseries of subjugated nations?" (316), invoking a fear common in the 1820s that American prosperity came at the cost of its virtue. Indeed, in condemning Rome, particularly its system of slavery and the bloodthirsty sport of gladiatorial contest, Spartacus celebrates his own innocence and freedom from the taint of Roman degradation, exclaiming "I thank the gods/There are Barbarians" (342).

As opponents are brought for Spartacus to fight, he refuses each one, claiming solidarity with them against Roman expansionism. Having finally agreed to fight (and kill) a Gaul, the praetor, Crassus, brings in another Thracian, who is in fact Spartacus's brother, Phasarius. This is the moment that sparks the slave revolt: Crassus insists that the two men fight, despite their fraternal relationship, and they almost immediately lead the rest of the slaves into rebellion, crying for "freedom and revenge!" (356).

Like Metamora's uprising, though, the slave revolt is doomed to failure. As more slaves join the rebellion, Spartacus's leadership is threatened, and his strategy is challenged. Bird's approach to this crisis in the plot is fascinating: Spartacus reminds his rival, Crixus, that the slaves chose him as a leader and swore to obey him - a curious combination of electoral democracy and military command. After invoking the power of the people to 
choose their leader, though, Spartacus observes that his election is particularly important because it was made by a heterogeneous group that came together under a common banner: "We are but one army,/With but one object, howsoe'er our ranks/Are filled with various nations./We are slaves,/All of us slaves, contesting for our freedom" (363). Sounding like a Jacksonian Democrat, Spartacus characterizes the slave army as a kind of voluntary association made up of disparate nations united for the cause of liberty, and making political decisions together. However, as Spartacus attempts to exert his elected authority, Crixus retorts "Thracian, I was a slave./But am not now" (364), raising the threat of democracy devolving into anarchy.

It is this simultaneous diversity of interests and centralization of power that is Spartacus's downfall. One by one, various national and/or political groups peel away from the larger rebellion to follow their own strategies, which end in disaster. By the end of the play, Spartacus has been abandoned by many of his allies and ultimately must surrender to the Romans. Unable to reconcile his roles as general and as representative of a barely cohesive "nation" of slaves, Spartacus ultimately falls to the Romans. The threat of unbridled anger and revenge raised in Metamora is intensified here, as thousands of former slaves take the place of the single Wampanoag chief. Indeed, the threat of mass violence is unvarnished in The Gladiator, and masculine fearlessness is translated into the reckless vengefulness of the mob.

It's striking that the lead male characters in all these plays are military leaders of one kind or another: Colonel Manly, Major André, Chief Metamora, and slave general Spartacus. In a world without aristocracy, the military seemed the closest to a meritocracy (although it certainly was not, as the class differences between officers and enlisted men made clear). Military command represents a necessary blending of unquestioned command and unquestioning duty: a comforting model for men increasingly adrift in an economic, social, and political world in which the rules were continually changing. However, military training requires loyalty and self-control: without the discipline of rank and hierarchy, soldiers can become simply men with deadly weapons and the knowledge of how to use them. Just as every democracy raises the specter of mob rule, mutiny and misrule lie in the shadow of the military.

Early American drama performs a crucial role in understanding the shifts in cultural and economic power in the postrevolutionary world. In presenting a wide variety of male identities, juxtaposing them with White masculinity, and constructing narratives that focused on conflict and its (often violent) resolution, early American drama forged and staged stories that were as instructive as they were entertaining, schooling their mostly male, often working class audiences in ideal citizenship. These productions created masculinity as both spectacle and object lesson, declamatory and explanatory, embodying the New American Man in all his splendor and his contradictions.

\section{Short Biography}

Sarah E. Chinn is an Associate Professor of English at Hunter College, CUNY. She holds a BA from Yale University and a PhD from Columbia University. Her work primarily explores questions of race, sexuality, and gender in US literature and culture, particularly in the 19th century. She teaches a wide range of courses from Nineteenth Century Women Writers to Early American Drama to Literary Theory to Multicultural American Literature. She is the author of Technology and the Logic of American Racism: A Cultural History of the Body as Evidence (Continuum, 2000) and The Invention of Modern Adolescence: Children of Immigrants in Turn-of-the-Century America (Rutgers University Press, 2008). She 
is currently working on two book-length projects: Spectacular Men: Early American Drama and National Masculinity, 1780-1830, and Feeling Our Way: The Ethics of Lesbian Writing. Her recent publications include an article on Audre Lorde in GLQ, on sexuality and disability in Radical History Review, and on the Hull-House Labor Museum in the collection Our Sisters' Keepers: American Women Writers and Poverty Relief. Professor Chinn just stepped down from her position as the Executive Director of the Center for Lesbian and Gay Studies at the CUNY Graduate Center.

\author{
Notes \\ * Correspondence: Hunter College, CUNY, 695 Park Avenue, New York, NY 10065, USA. Email: sarah.chinn@ \\ hunter.cuny.edu
}

1 As Arthur Hornblow points out in his 1919 History of the Theatre in America, "[t]he probability is that the laws forbidding play-acting remained a dead letter in many of the large towns at least, the regulations governing the players being introduced more to placate public opinion at the moment than with any serious intention of suppressing the player altogether as a public nuisance. How else can we account for the theatrical performances in New York in 1702 and again in 1732 or for the performances given in 1714 in Boston and Philadelphia?” (25). Nonetheless, these laws were occasionally enforced: Mark Caldwell quotes Royall Tyler's reminiscences of a sub rosa performance of Addison's Cato in the late 1760s in Boston that was raided by constables and several performers and audience members were hauled off to court. Caldwell argues that "in Boston drama ... remained an endangered and highly suspect pastime" until the 1790s (310).

2 The proliferation of theater companies in the mid-Atlantic states in the early 1790s was due in part to the competition between Hallam and his erstwhile star Thomas Wignell. After an acrimonious break with the American Company, Wignell struck out on his own. According to William Dunlap, as soon as Wignell and Hallam established rival companies in several cities, including New York, Philadelphia, and Baltimore.

3 This format goes back to the beginnings of organized American theater, as Edwin Wolf 2nd shows in his review of colonial playbills.

4 This conundrum creates its own paradox; as Fliegelman argues, "[i]n a world where appearance and public perception constitute a primatry reality, character becomes synonymous with public estimation or reputation ..., less a fixed, indwelling moral nature than a fluid and vulnerable social identity" (125).

5 Jeffrey Richards argues at length in Drama, Theatre, and Identity in the American New Republic that American playwrights leaned heavily on British theatrical models and that since American audiences demanded plays that "reflected both the American situation and contemporary theatrical taste, American authors had little choice but to craft their works upon London models" (for example, Jonathan is a Yankee version of Darby, the Irish soldier with whom Wignell made his name as a comic actor) (90).

6 Michael Zakim's fascinating book Ready-Made Democracy: A History of Men's dress in the American Republic, 17901860 makes a similar argument in relation to men's clothes. Despite the romanticizing of homespun fabric and home-sewn clothes, the clothing business grew considerably at the end of the 18th and beginning of the 19th centuries, and cities were the major producers of that clothing.

7 Interestingly, while Seward wishes that "mid-way between these sever'd worlds [of Britain and America],/Rose barriers, all impassable to man,/Cutting off intercourse, till either side/Had lost all memory of the other!" M'Donald looks forward to a time after the revolution in which Europe will freely trade with the newly free country with both commerce and knowledge, a striking image of liberty as the freedom of the marketplace (529).

\title{
Works Cited
}

Bird, Robert Montgomery. 'The Gladiator (1831).' The Life and Dramatic Works of Robert Montgomery Bird. Ed. Clement Foust. PhD Dissertation, University of Pennsylvania, 1919.

Brooks, Peter. The Melodramatic Imagination Balzac, Henry James, Melodrama, and the Mode of Excess. New Haven: Yale University Press, 1995.

Caldwell, Mark. 'Defining American Urbanity: Royall Tyler, William Dunlap, and the Postrevolutionary Theater in New York.' Early American Studies 7.2 (Fall 2009): 309-32.

Clarke, Mary Carr. 'The Fair Americans.' Plays by Early American Women, 1775-1850. Ed. Amelia Howe Kritzer. Ann Arbor: University of Michigan Press, 1995. 183-216.

Dunlap, William. 'André (1798).' Representative Plays by American Dramatists: Vol. 1, 1765-1819. Ed. Montrose J. Moses. New York: E.P. Dutton \& Co., 1918. 499-564. 
2005

Fliegelman, Jay. Declaring Independence: Jefferson, Natural Language, and the Culture of Performance. Stanford: Stanford University Press, 1993.

Grimsted, David. Melodrama Unveiled: American Theater and Culture, 1800-1850. Chicago: University of Chicago Press, 1968.

Hornblow, Arthur. A History of the Theatre in America, From Its Beginnings to the Present Time. Philadelphia: J.B. Lippincott, 1919.

Nelson, Dana. National Manhood: Capitalist Citizenship and the Imagined Fraternity of White Men. Durham: Duke University Press, 1998.

Richards, Jeffrey H. Theatre, and Identity in the American New Republic. Cambridge: Cambridge University Press, 2005.

Rinehart, Lucy. "“Manly Exercises": Post-Revolutionary Performances of Authority in the Theatrical Career of William Dunlap.' Early American Literature 36.2 (2001): 263-93.

Stone, John Augustus. 'Metamora; Or, The Last of the Wampanoags (1829).' America's Lost Plays, vol. XIV. Ed. Eugene R. Page. Princeton: Princeton University Press, 1941. 1-40.

Tyler, Royall. 'The Contrast (1797).' Early American Drama. Ed. Jeffrey H. Richards. New York: Penguin Books, 1997. 6-57.

Wolf, Edwin 2nd. 'Colonial American Playbills.' The Pennsylvania Magazine of History and Biography 97.1 (Jan., 1973): 99-106.

Zakim, Michael. Ready-Made Democracy: A History of Men's Dress in the American Republic, 1760-1860. Chicago: University of Chicago Press, 2003. 